\title{
Erratum: Psalm 27:4 - To reflect in his temple: Communion with YHWH as the culmination of the journey of life
}

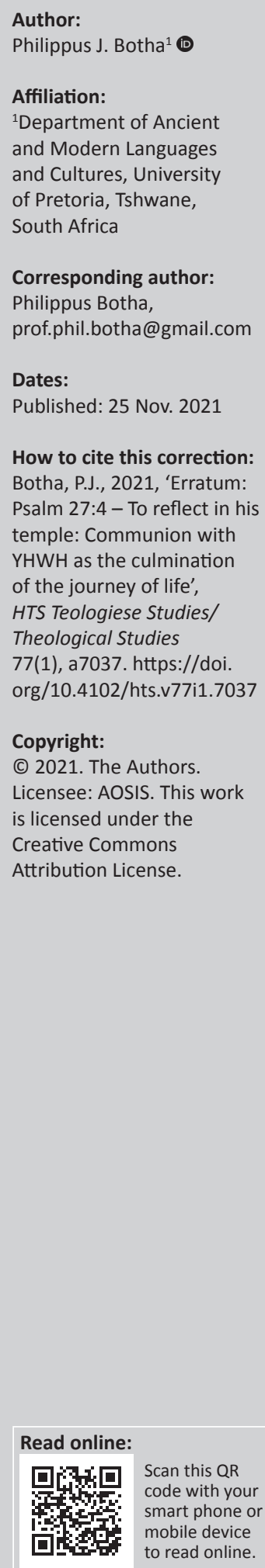

Corresponding author:

Philippus Botha,

prof.phil.botha@gmail.com

Dates:

Published: 25 Nov. 2021

How to cite this correction: Botha, P.J., 2021, 'Erratum:

Psalm 27:4 - To reflect in his temple: Communion with YHWH as the culmination of the journey of life', HTS Teologiese Studies/ Theological Studies 77(1), a7037. https://doi. org/10.4102/hts.v77i1.7037

\section{Copyright:}

(C) 2021. The Authors. Licensee: AOSIS. This work is licensed under the Creative Commons Attribution License.

In the version of this article initially published, Botha, P.J., 2021, 'Psalm 27:4 - To reflect in his temple: Communion with YHWH as the culmination of the journey of life', HTS Teologiese Studies/ Theological Studies 77(4), a6623. https:/ / doi.org/10.4102/hts.v77i4.6623, the article issue number was given incorrectly. The correct issue number should be number 1 instead of number 4 .

The article's 'Note' section on page 1 was also given incorrectly. The note should read 'Note: Special Collection: Historical Thought and Source Interpretation, sub-edited by Johann Cook (SUN)' instead of 'Note: Special Collection: Historical Thought and Source Interpretation'.

This correction does not alter the study's findings of significance or overall interpretation of the study results. The publisher apologises for any inconvenience caused. 